\title{
Promoting mathematical thinking in Finnish mathematics education
}

\author{
Krzywacki, Heidi
}

Sense publishers

2016

Krzywacki , H , Pehkonen , L \& Laine , A 2016 , Promoting mathematical thinking in Finnish mathematics education . in H Niemi , A Toom \& A Kallioniemi (eds), Miracle of education : The principles and practices of teaching and learning in Finnish schools . Second revised education edn , Sense publishers , Rotterdam , pp. 109-123 . https://doi.org/10.1007/978-94-6300-776-4_8

http://hdl.handle.net/10138/230280

https://doi.org/10.1007/978-94-6300-776-4_8

acceptedVersion

Downloaded from Helda, University of Helsinki institutional repository.

This is an electronic reprint of the original article.

This reprint may differ from the original in pagination and typographic detail.

Please cite the original version. 
PROMOTING MATHEMATICAL THINKING IN FINNISH MATHEMATICS EDUCATION

Heidi Krzywacki, Leila Pehkonen \& Anu Laine

University of Helsinki

\section{Abstract}

In this article, we outline some of the main characteristics of the mathematics education in the Finnish educational context. In Finland, at both primary and secondary school levels teachers are educated to be autonomous and reflective academic experts. This policy means there is a strong emphasis on teachers' independence and autonomous responsibility and it also has many consequences for teaching mathematics. We start by discussing the main features of Finnish mathematics education through the outline stated in the National Core Curriculum and reflecting on the features of teacher education, which prepares academic, pedagogically thinking teachers for school work. In Finland, mathematics education is highly dependent on teachers and their understanding of teaching and learning mathematics. Secondly, we elaborate the practical and environmental aspects influencing schooling and the way mathematics is taught in Finnish comprehensive schools. The central aspects characterising Finnish mathematics education, such as the distribution of lesson hours, the availability of pedagogically well-structured learning materials and the principles of school assessment, are discussed. To conclude, Finnish teachers responsible for teaching mathematics play a significant role in maintaining and developing the quality of school mathematics education.

Keywords: mathematics education, comprehensive school, curriculum, teacher education

\section{Introduction}

In Finland, basic education in mathematics is carried out by primary school teachers, responsible for the first six years of schooling, i.e., grades 1-6 when pupils are 7 to 12 years old, and by specialised subject teachers, who teach mathematics at secondary school level in grades $7-9$ when pupils are 13 to 16 years old. In practice, Finnish primary school teachers teach more than two thirds of mathematics lessons in comprehensive school. The achievements of Finnish pupils are, at least to some extent, based on the high-level academic teacher education implemented in Finland (see more in Chapter 2). Obviously, the number of initial teacher education courses, which are intended to give student teachers expertise in teaching and learning mathematics as well as those for special interests in mathematics 
education, differ for teachers at different school levels. Especially, primary teacher education programmes have always been popular; only about 10 per cent of the gifted and talented applicants are accepted. Even though becoming a mathematics teacher at the secondary school level is less popular, there is no lack of qualified subject teachers in mathematics in Finland. Teachers in Finnish comprehensive schools are not only well educated academic experts with university master's degree, but they are also motivated, autonomous professionals, who are relatively committed to their work (Simola \& Hakala 2001; Simola 2002).

The outcomes of Finnish mathematics education have proved to be excellent according to PISA testing (OECD 2004; OECD 2010; see more in Chapter 1). The success is actually not surprising considering the development of mathematics education during the past thirty years. From the late 1980s, serious efforts were made to develop mathematics teaching and learning in schools. At that time, an informal voluntarily established committee, 'Mathematics teaching in the 1990s, was formed by experts in mathematics teaching at different levels, publishers, researchers and administrators. Teachers had an essential role in the committee, which discussed the future and the need for reforms in mathematics education. After two years of continuous informal meetings, a booklet about the main outcomes and recommendations for the further development of Finnish mathematics education, for example, some practical ideas and examples of exercises, was published (Halinen et al. 1991). The committee was successful in sketching upcoming and current developmental trends in mathematics education. The booklet became an important trailblazer for future reforms among others the curriculum reform in 1994.

There has been a clear trend to improve Finnish mathematics and science education in general. In 1995, the National Board of Education launched a national development project, the LUMA - project (LU refers to science and MA to mathematics) that lasted from 1996 until 2000 (Heinonen 1996). The aim was to strengthen knowledge and skills in mathematics and science education at all levels of schooling, while providing special attention to the significance of learning the respective subjects. There have not been dramatic changes in Finnish education in the $21^{\text {st }}$ century; although the spirit of developmental work and special attention to mathematics and science education is still there. The national LUMA Resource Centre coordinated by the University of Helsinki has continued the developmental work as an organisation that oversees cooperation between schools, universities and industry. The aim of the activities is to promote and improve education in natural science, mathematics, computer 
science and technology at all levels. However, some critical voices can be heard when discussing the quality and competence of the students entering mathematical programmes in higher education institutions. According to the responsible providers of education, the computational skills and mathematical routines of students starting at their institutions do not meet all their expectations, and therefore the challenge still remains of how to achieve the learning aims set by the respective study programmes. Ministry of Education and Culture has launched a national development project for years 2014-2019 in order to develop the teaching of natural sciences and mathematics in pre- and basic education. The project is administered by Luma Suomi network.

In this article, we outline the characteristics of Finnish mathematics education by discussing teaching and learning school mathematics, the core idea of mathematics education described in the national curriculum and the school environment influencing the implementation of school mathematics. We elaborate on Finnish mathematics education especially from the perspective of the teachers, who can be seen as autonomous professionals, meaning that they are responsible for the planning, implementation, and assessment of teaching and learning mathematics. As a result of the autonomous role of the teachers, the nature of teaching mathematics in Finnish classrooms is highly dependent on individual teachers.

\section{The starting point of Finnish mathematics education}

There are two essential aspects, which have an impact on the way mathematics education is carried out in Finland: the outline of mathematics education described in the National School Curriculum, by which teachers are bound when teaching mathematics in their classrooms, and teacher education organised by the universities. Teachers, both at the primary and secondary school levels, have an essential role in implementing the core ideas of mathematics education.

\section{The core idea of mathematics education according to the national curriculum}

The previous national core curriculum, the Framework Curriculum for the Comprehensive school (FCCS 1994) published in 1994 by the National Board of Education was an important basis for successful mathematics education in Finland. Before that, in the 1980s, the National School Curriculum was a more detailed document setting the aims for and describing the contents of various school subjects. The main change took place when the curriculum was written giving special emphasis to the spirit of constructivism. The 1994 FCCS was much more flexible, less centralised and detailed than its predecessors (see more in Chapter 6). All 
Finnish teachers truly became involved in curriculum planning and writing, although not all the teachers were responsible for mathematics.

Problem solving - both as a method and as content - was set as an underlying principle along with mathematical-logical requirements. In addition, teaching geometry, statistics and number concept as well as proper basic counting skills were widely discussed. Stress was laid on pupils' thinking and understanding mathematics, and co-operative learning methods were emphasized. In addition, it is clarified in the curriculum that: "pupils of all ages and all levels should be allowed to build and make models with their hands in order to form correct mental pictures and concepts' (ibid. 83). Various, easy-produced, non-expensive and self-made manipulatives and a range of exercises were introduced in the support material. In practice, the ethos and practical examples provided in the documents are consistent with the tasks used in PISA testing.

The latest educational and psychological research on learning mathematics was taken seriously into consideration in the 1994 FCCS and consequently, the main changes in mathematics education took place almost 30 years ago. However, it was found to be to put into practice, the main ideas of Finnish school education described in the broad outline, even if additional support materials (Opetushallitus 1995) were provided to support understanding and practically implementing the new ideas of mathematics education. The current core curriculum (Opetushallitus 2014) differs from the curriculum from 1990's in some ways, even if neither the spirit of Finnish comprehensive school in general, nor the underlying ideas of constructivist mathematics education have changed. The current curriculum takes more control over the contents of teaching and learning, and consequently, the overall outline of education is described in more detail. Mathematics education is considered as the basis for developing mathematical and logical thinking, which are seen to be potentially important for societal activities in the future. Since learning mathematics is seen to be abstract and challenging for children to understand, the need to use didactical models and concrete materials such as manipulatives should be addressed in good mathematics teaching. In addition to transforming mathematics into something more visible and concrete, applying mathematical thinking in practice and emphasising the importance of reasoning are also at the focus of the learning goals. Students should learn how to reason their thinking and communicate mathematical processes with other learners. The importance of problem solving skills is stressed. The essential aim of learning mathematics is to acquire a thorough 
understanding of mathematical concepts and based on that, learn how to apply the acquired knowledge in different situations. In addition, the recent core curriculum raises the importance of improving pupils' self-confidence and positive attitudes towards mathematics. To conclude, the current national curriculum still outlines only the main principles of teaching mathematics in Finnish schools without going into detail. The details are elaborated in the local level curricula.

\section{Teacher education and the main principles of good mathematics education}

Finnish teachers have a comparatively autonomous role in teaching mathematics in their classrooms, and therefore, teachers' beliefs, skills and knowledge-base of mathematics education and their potential to put the ideas into practice matter (Krzywacki 2009). Teachers face challenges at many levels when they teach mathematics. However, Finnish teachers are committed to addressing these demands and they do so in their own individual ways. This, in turn, puts weight on the quality of teacher education, and how well the initial education of teachers manages to provide a starting-point for expertise in teaching mathematics. Since each Finnish university is allowed to design its teacher education programmes a bit differently, there are minor differences between the implementation, amount and contents of mathematics education courses (Laine \& Kaasila 2007; see more about teacher education in Chapter 2). Here, we will use teacher education at the University of Helsinki as an example.

In the initial primary school teacher education, mathematics education is a special focus among the multidisciplinary courses providing readiness for teaching all school subjects at primary school level. In practice, the extent of mathematics education course at the University of Helsinki is 7 credit points (cp) out of the total 300 credit points comprising the overall programme. In addition to the basic course compulsory for all student teachers, they all teach mathematics during their teaching practice periods that provide actively mentored and supervised teaching experience $(20 \mathrm{cp})$. Only some of the teacher students specialize in teaching mathematics through extended studies. Some 10 to 15 percentage of the primary school teacher students complete 25 credit points of advanced mathematics education courses, comprising of mathematical courses and the courses dealing with teaching and learning mathematics, such as special needs in mathematics education. It is also possible to complete a minor (60 credit points) specialising in teaching mathematics at lower secondary school. Only 5 per cent of the students complete these studies comprising mostly of the mathematical courses provided at the Department of Mathematics and Statistics. 
In secondary school teacher education, at the University of Helsinki as well as other Finnish universities, a major in university mathematics is the main component of the degree that takes approximately five or six years to complete (see more about teacher education in Chapter 2). The programme is grounded on building up strong mathematical content knowledge, i.e., the programme consists of university mathematics as a major $(150 \mathrm{cp})$, another school subject such as chemistry or physics (60 cp), and one year of pedagogical studies (60 cp) that includes supervised teaching practice modules $(20 \mathrm{cp})$. Pedagogical issues are discussed in general educational courses (20 cp), as well as special features of teaching and learning mathematics in the special courses of mathematics education $(20 \mathrm{cp})$. The production of a small-scale pedagogical dissertation in mathematics education is also part of the studies.

Here, we introduce four themes characterising the spirit of mathematics education that are mediated in pre-service teacher education at Finnish universities. Even if the structure of the teacher education programmes are varied, a common foundation is laid for quality mathematics teaching and learning. First, affective aspects are considered important to studying and learning mathematics. Traditionally, both in Finland and internationally, the outline of mathematics education has been established through describing cognitive aspects and the aims of learning outcomes regarding mathematical skills and knowledge. However, Finnish educators have started to underline the importance of views and attitudes towards mathematics (Hannula 2004; Pietilä 2002). The need for improving positive attitudes and interest towards mathematics is also mentioned in the current national curriculum (Opetushallitus 2014). When affective aspects are also considered in outlining educational aims there is a broadening of the traditional learning aims in mathematics education.

Second, the use of concrete materials and didactical models for improving the understanding of mathematical concepts is also seen as an underlying theme of Finnish mathematics education. This is discussed during the teacher education courses, for example, in group activities and when piloting the use of concrete materials in teaching practice. In the teacher education programme at University of Helsinki, the main idea behind number systems are elaborated with the help of concrete materials, which help students to understand the main mathematical concepts and consider how to take this special viewpoint into consideration in their teaching, especially through identifying the difficulties that learners might face when learning the ten-base system. 
Third, problem solving and the significance of reasoning and thinking processes are also addressed in the pre-service teacher education. Traditionally, the process of teaching and learning mathematics, whether in Finnish schools or internationally, has not underlined the importance of oral communication and co-operative methods in mathematical processes. However, since interaction with peers enhances the need for communicating about the processes and the reasons underpinning them, co-operative learning and working in pairs or in small groups are regarded as workable methods for promoting skills in problem-solving (Good, Mulryan \& McCaslin 1992). The emphasis is on learning to process complex mathematical situations in a flexible and creative manner. When working together with others, learners are in a situation, where speaking about mathematical problems and the phases of the solution process is necessary. It is natural to speak about processes and give reasons for making decisions on how to carry out procedures when sharing one's understanding with others.

The fourth theme is related to understanding and supporting students, who have learning difficulties with, and special needs for, mathematics learning. Teachers in comprehensive schools, especially those teaching the first grades of primary school, should have a basic knowledge about learning difficulties and dyscalculia, and based on that, be able to recognise learners who might need some extra support in learning mathematics. Often the question is not about serious learning problems but recognising some common misconceptions and minitheories, i.e., rules and misconceptions developed by the pupils themselves that are common in mathematics (Claxton 1993). In addition to recognising pupils with challenges in learning mathematics and providing extra support in problematic situations, it is essential to possibly prevent difficulties in learning through taking into consideration the most common minitheories related to different mathematical content, for example, through using manipulatives in teaching and learning fractions and providing parallel tasks, which help learners in the conceptual changes associated with understanding the characteristics of rational numbers (Merenluoto \& Lehtinen 2004).

\section{Implementation of mathematics education in Finnish comprehensive schools}

In the following, we outline some environmental and practical features that influence the way mathematics is taught and studied in Finnish comprehensive schools. 


\section{Distribution of lesson hours in mathematics}

In the OECD countries, the total number of hours devoted to mathematics teaching in Finnish schools is only larger than those of the Netherlands (Välijärvi et al. 2002, 262), i.e., 32 hours of lessons hours a week are allocated for teaching and learning mathematics during the nine years of comprehensive school. Time is not wasted on mathematics education in Finnish comprehensive schools, although the number of mathematic lesson hours is higher than that given to most other school subjects. In fact, only mother tongue studies have more lessons hours than mathematics. The Council of State gave its latest decision on the distribution of lesson hours in 2012 (The new distribution of lesson hours in basic education)..

According to the decision, mathematics must be taught for at least 6 lesson hours a week (i.e. 18 times 45 minutes) during the first two years at the primary level of comprehensive school, at least 15 hours a week during grades 3-6 and at least for 11 hours a week during the three years (grades 7-9) at the upper level of comprehensive school. This means approximately 3 to 4 hours a week at the primary school level as well as at the lower secondary level. In a similar way, minimum hours per week were given for all school subjects as well as the maximum hours pupils were allowed to work at school. However, no hourly maximum limits were set for any school subject. In addition, the local curriculum level must be set so that pupils are eligible to continue their studies at the next school level even if they had studied the minimum amount of mathematics set by the decision of the Council of State. Within these constraints, the schools are responsible to make their own decisions about the distribution of lesson hours.

\section{Learning materials as a resource for teaching and learning}

Learning materials, especially pupils' textbooks have an important role in Finnish mathematics education. Finnish primary school teachers are especially very loyal to their mathematics textbooks - as are teachers all over the world. In Finland, primary school teachers have always been very satisfied with the mathematics textbooks and teacher's support materials. According to a study by Niemi (2004), 53\% of teachers in the sixth grade found that textbooks are a better base for the planning mathematics teaching than the school's own curriculum. This is in conflict with the underlying principle of local level curriculum work. Secondary school teachers have a slightly different attitude towards ready-made learning materials. They rely on their expertise in mathematical content knowledge and specialisation in teaching and learning mathematics, and therefore, the need for support 
material and ready-made pedagogical ideas is different at the primary and secondary school levels. This can be seen also in the supply of support materials.

In Finland, learning materials are produced by ordinary teachers, who are interested in mathematics education and currently working at schools. Therefore, they are very familiar with the conditions in schools. Currently, there are several parallel textbooks from different publishers, i.e., 5 or 6 textbooks at the primary level and 4 to 6 at the secondary school level. Even if the textbooks differ slightly from each other, all the learning materials and textbooks are generally speaking rather similar. All textbooks provide various materials for problem solving and statistics, ideas for group work and projects. They also provide a good supply of basic exercises as well as more complicated tasks for all the pupils. There are also collections of challenging tasks for those pupils who are more advanced or/and interested in mathematics. It is the teachers' responsibility to choose the textbooks and other materials for their pupils as well as the teaching methods. It is noteworthy that the quality of the learning materials is not directly equivalent to the quality of teaching, as the teacher can use all kinds of materials either appropriately or otherwise. They can also choose to teach without textbooks if they want to, although this alternative is seldom used.

Teachers' conceptions of teaching and learning materials in mathematics reveal something about Finnish mathematics education. In a case study (Pehkonen 2004b), nine primary teachers were interviewed about what constitutes good and stable elements in school mathematics teaching and learning. The mathematics textbooks were seen as important tools for teachers in maintaining their teaching at an appropriate level and providing ideas for new ways to teach. This justification was revealed by the teachers speaking appreciatively about the textbooks and their use in mathematics education and of positive accounts of using textbooks. Teachers claim that the textbooks guarantee a stable quality of teaching, since they are considered to be logical and explicit. They contain the essential facts and the tasks are connected to everyday life. In addition, the use of textbooks was seen as a means for teachers to keep their teaching logical and coherent. Mathematics textbooks help teachers with their workloads, because the books provide ready and sensible structures for lessons and enough exercises for the pupils.

Actually, mathematics textbooks were considered to be written for pupils and their learning processes. Moreover, textbooks were seen to be a source of motivation; they are colourful and 
the exercises are varied. The pupils' keen interest was seen as evidence of their high quality. Teachers of the youngest children claimed that children love their mathematics books. As nowadays most schoolwork is organised in small groups, teachers find that pupils love those peaceful moments when they are allowed to work alone and proceed at their own pace. The shared belief is that, with the help of textbooks, children can study the facts they are expected to learn.

Nowadays, other kinds of learning materials and computer-aided facilities are increasingly used in Finnish schools. Teachers can choose what they use and how to use these modern facilities in a way that suits their personal teaching styles. Even if Finnish schools are rather well equipped (Eurydice 2004; Eurydice 2011), the challenge lies in using these resources in meaningful ways from the perspective of learning mathematics. The technological materials are often related in a complementary way to existing learning materials, such as book series. In accordance with the underlying idea of using concrete materials and didactical models in teaching and learning mathematics, textbooks also include some print versions of manipulatives, for example, materials for illustrating the ten-base system and basic calculations during the first grades in primary school. There are also additional materials attached in teacher guidebooks, for example, geometrical obstacles to be used by teachers in teaching and learning geometry.

In Finland, teacher guidebooks are structured to support teachers in their everyday teaching work. The main idea of the guidebooks are to provide help in designing mathematics lessons and give ideas for implementing the main underlying ideas of mathematics education in Finland. In practice, the pedagogical ideas provided in the teacher guidebooks are presented in parallel with a learner's page view and structured in accordance with traditional parts included in mathematics lessons (see Illustration 1: Best practice example).

Illustration 1. Best practice example: a mathematics lesson in a teacher's guidebook (Lilli et al. 2010). 


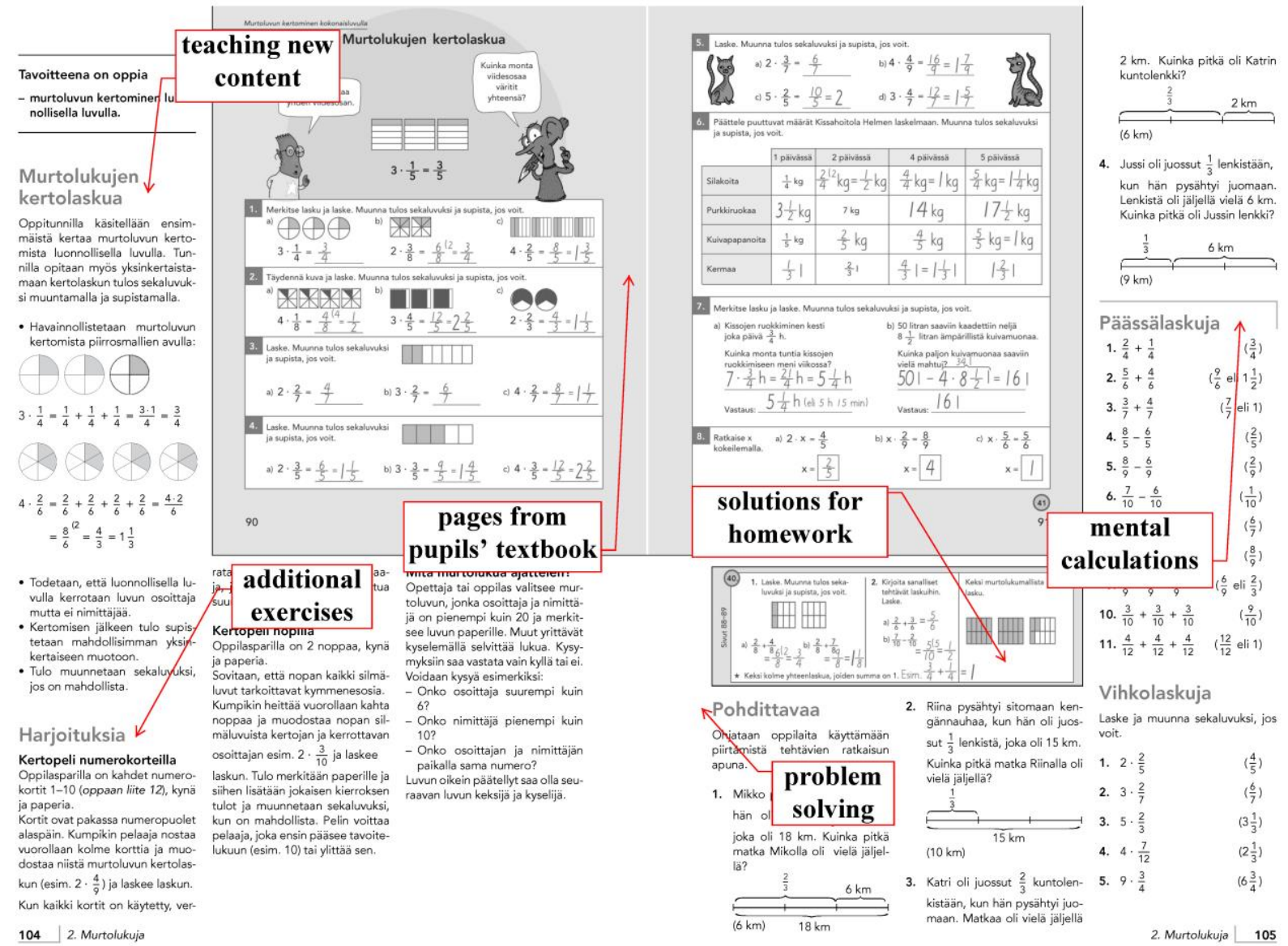

\section{Teaching mathematics in Finnish classrooms}

We cannot claim that Finnish mathematics education uses very innovative teaching approaches. The fact is that teaching in general, especially in mathematics teaching, practices are rather traditional in Finnish classrooms (Andrews et al 2014; Norris et al. 1996). In mathematics, teaching is mainly teacher-centred frontal teaching of the whole group of pupils but nevertheless the frequency of pupil activity and involvement are high. Although there is a good deal of conservatism in the teaching methods, focusing on this alone does not give the whole truth. Finnish teachers avoid being too hasty and want to guarantee learning opportunities for their pupils. They try to avoid 'educational entertainment' (Pehkonen 2007). However, teachers do adopt new ideas and methods that they find meaningful and useful. For example, some teachers have a special mathematics lesson with problem solving or project work once a week. According to Niemi (2004), more than $60 \%$ of primary school teachers state that they use a lot or quite a lot of various co-operative teaching methods in their mathematics lessons. 
It seems that Finnish teachers have found a successful way to combine traditional teaching methods with some innovative approaches. Some traditions and routines have proved to be very fruitful and the structure of an average mathematics lesson is rather unchangeable. It has been a tradition for decades that a short time, about a 5-minute session at the beginning of a mathematics lesson is devoted to mental calculation or some other orientation activity. All teachers' support materials provide a collection of mental exercises for every lesson to help the teachers. Even if the time used for this kind of practising is short, it is repeated from lesson to lesson from one year to the next.

Usually, what follows is checking the homework that is given after each mathematics lesson in order to repeat the main points of the previous lesson. However, even if Finnish pupils use less time on their regular mathematics homework than their peers in most OECD countries (Välijärvi et al. 2002, 262), homework has a special role in Finnish mathematics classrooms. Most teachers make a quick round of the classroom and make sure that all the pupils have completed their homework. Usually, difficult or complicated tasks are explained by selected pupils to the rest the class. Consequently, the pupils are regularly given plenty of feedback about their homework. Negative feedback is not given if pupils are unable to complete their homework but their parents are informed if they do not do their homework.

The lesson continues with the teacher introducing and teaching new topics, which is followed by individual work through tasks that help the learners study and acquire the knowledge set in the lesson aims. The guidebook highlights some essential pedagogical ideas that a teacher should take into consideration when discussing a topic. A large proportion of mathematics lessons are devoted to silent, individual work. The pupils can practise at their own pace and teachers help those who need support. Individual work is very consistent with the ideas of constructivism, although it is not a new and modern way of working. Homework is usually given to the pupils at the end of the lesson to promote the learning process.

\section{Assessment policy}

As Finnish teachers have a considerable amount of decision-making authority in schools they can, among other things, determine quite a lot of their course contents and pupil assessment policies. Finnish pupils are not assessed by national tests or examinations, which emphasise the importance of teacher-conducted assessment practice. On the national level, the outcomes of the Finnish comprehensive school are followed only by sample-based surveys at the end of 
the sixth and ninth grade of comprehensive school. The results are published only at the system level, while the results of individual schools are delivered exclusively to the schools concerned.

In the 1990s, the principles of pupil evaluation were reformed in conjunction with the curriculum reform. The main principle was no longer to find differences between pupils - as it had been earlier - but to improve pupils' learning. The main goal was to determine how to help pupils better understand mathematics. Various methods in pupil assessment were introduced, for example, how to evaluate pupils' mathematical processes and how to evaluate products. At that time, pupil self-assessment was a totally new idea in Finnish education, but very soon it was adopted at all school levels. Assessment is seen as a natural part of learning process and inform both a teacher and students about teaching and learning mathematics.

All Finnish teachers are taught to design and implement assessment in mathematics during their pre-service teacher education. Primary school teachers are capable of designing their own tests and assessment tools. All primary school mathematics textbooks provide collections of ready-made tests, and teachers can use them if they want as an additional resource. Naturally, the use of these tests is one method to reach some uniformity in assessment. Anyway, as all teachers are involved in the process of planning the school curriculum the fact is that Finnish primary teachers are very well aware of the curricular goals for mathematics. In addition, they know what contents and to which level children are expected to learn mathematics.

\section{Talent development for all students}

A law (Basic Education Act 1998/628) regulates the compulsory education of all Finnish children. The central point of the Basic Education Act is that education and teaching must be arranged so that it takes into account the pupils' ages and capabilities.. The present law puts great emphasis on equity and uniformity in basic education throughout the country. These principles can also be seen in the Development Plan in Education and Research published by the Ministry of Education for the years 2011-2016. This document states that

'The child's right to safe and high-standard instruction in a neightbourhood scholl will be quaranteed' and

'Basic education will be developed as uniform instruction catering for the whole age group and securing equal prerequuisites for all' (ibid. pp. 24-25). 
One of the leading principles in the Finnish education policy has been to provide all pupils with equal and high-quality educational opportunities and to remove obstacles to learning especially among the least successful pupils. Help is given most during the first school years. This has been the Finnish educational mission for decades. It can be seen as an ideological standpoint, but it has its pragmatic perspective as well. Educational equality has been seen as an investment in human capital. Small nations, like Finland, cannot afford to waste any reserve of talent. In the light of PISA findings, we seem to have managed very well in these aims (e.g., OECD 2004, 144-145; OECD 2010).

According to the Basic Education Act, schools must cooperate with parents/ carers. These principles create the opportunities for education of all pupils' with different capacities and talent. Good co-operation between school, carers and pupils is a requisite in providing adequate support in learning and school-going. The sooner special needs as a learner are recognised, the better schoolteachers can provide support in learning process and possibly avoid difficulties in the future. The law defines the support as three-step model from part-time to enhanced and further to special-needs support.

Gifted pupils are not mentioned as a special group in any law or official document regulating Finnish school education. Gifted education pedagogy as such is not typical to the Finnish school system, meaning that it is not taken into consideration significantly in everyday schooling. However, it can be said that opportunities are provided for developing the talents of all pupils in accordance with their needs (Pehkonen 2004a). However, much is dependent on a teacher's interests and talents. The size of teaching groups varies, and furthermore, there are different kinds of learners integrated in heterogeneous classes. Especially at the primary school level, it might be difficult for primary school teachers who have not specialized in mathematics to provide academic challenges for any of their pupils who are exceptionally gifted in mathematics.

To conclude, the Finnish view on education and giftedness is to concentrate more on talent development than on gifted education. This does not mean leaving the most able and capable pupils without special nurturing, but the main concern is to develop the talents of all the pupils and take special care of those with learning difficulties. The full use of all talent reserves is a challenge to Finnish education and an investment for the future. Educational equality is promoted by providing special needs education in mathematics as part of 
mainstream schooling. The idea is to support students with different talent profiles individually in mixed classes, not by grouping the pupils based on their mathematical talents but dealing with their individual needs through special lessons and exercises designed in cooperation with special needs education teachers.

\section{Concluding remarks}

Finnish pupils seem to like mathematics especially at the primary school level based on studies that have found pupils' attitudes towards mathematics to be quite positive. According to Kupari (1999), mathematics was one of the five most popular subjects among $4^{\text {th }}$ and $6^{\text {th }}$ graders. The attitudes are most positive during the first school years. However, over time attitudes seem to turn less positive. Niemi (2008) has found that sixth-graders had still mildly positive or neutral attitudes (scale from -2 to $+2 ; M=0,5$ ) and in 2004 he reported that onethird of sixth graders claimed that mathematics was their favourite school subject. It is noteworthy that expressing strong emotions or feelings is not typical in Finnish culture, and consequently, learning mathematics is not considered in an emotional manner either. Finnish pupils have mostly very sensible and neutral attitudes towards schooling and mathematics is seen as an important and useful school subject rather than something to be emotional about (Niemi 2004, 151-152).

We have presented the outlines of teaching and learning mathematics in Finnish comprehensive schools in order to describe the facilities influential to functional mathematics education in Finland. One of the features characterising mathematics education in the Finnish education system is the independent role of the teacher. Although primary school teachers are not usually experts in mathematics, they are professionals in teaching and education. All teachers have a solid knowledge base in education and appropriate skills for self-development in work. At the secondary school level, specialised subject teachers are responsible for teaching mathematics. They are experts in their respective subject, and most of them are deeply interested in developing their methods of teaching mathematics and promoting learners' interest in mathematics learning. Teachers know how to develop skills, nurture talent and to take care of the overall wellbeing of a child. Even if mathematics teaching seems to be quite traditional in Finnish classrooms (Andrews et. al 2014; Norris et al. 1996), the teaching and learning process is guided by professionals who are aware of the learning objectives within the core curricula. It is one of the teachers' responsibilities to choose appropriate activities and materials to implement these objectives. Using teacher-conducted assessments 
instead of national tests and examinations especially gives teachers enough scope to independently plan and teach mathematics. Teaching and learning mathematics at the primary school level seem to provide a good and sound basis for studies at the upper secondary level. Finnish teachers have shown that there are many ways to teach mathematics well.

\section{References:}

Andrews, P., Ryve, A., Hemmi, K. \& Sayers, J. (2014). PISA; TIMSS and Finnish mathematics teaching: an enigma in search of an explanation. In Educational Studies in Mathematics DOI 10.1007/s10649-014-9545-3

Basic Education Act [Perusopetuslaki] 21.8. 1998/628.

Available in: http://www.finlex.fi/en/laki/kaannokset/1998/en19980628.pdf.

Claxton, G. (1993). Minitheories: a preliminary model for learning science. In: P.J. Black \& A.M. Lucas (eds.) Children's informal ideas in science. (pp. 45-61). London: Routledge.

Eurydice (2004). Key Data on Information and Communication Technology in Schools in Europe. 2004 edition. The information network on education in Europe. Available in: http://eacea.ec.europa.eu/education/eurydice

Eurydice (2011). Key Data on Learning and Innovation through ICT at school in Europe Available in: http://eacea.ec.europa.eu/education/eurydice

FCCS (1994). Framework curriculum for the comprehensive school 1994 (in Finland). Helsinki: State Printing Press and National Board of Education.

Good, T. L., Mulryan, C. \& McCaslin, M. (1992). Grouping for instruction in mathematics: A call for pragrammatics research on small-group process. In D. Grouws (Ed) Handbook for research on mathematics teaching and learning. (pp. 165-196). New York: MacMillan.

Halinen, I., Hänninen, L., Joki, J., Leino, J., Näätänen, M., Pehkonen, E., Pehkonen, L., Sahlberg, P., Sainio, E., Seppälä, R. \& Strang, T. (1991). Peruskoulun matematiikan opetuksen kehittämissuunnasta 1990-luvulla. [About the developing trends in mathematics 
education in the comprehensive school in 1990's] Opetus ja kasvatus. Helsinki: VAPKkustannus.

Hannula, M. S. (2004). Attitude towards mathematics: emotions, expectations and values. Educational Studies in Mathematics 49 (1), 25-46.

Heinonen, O-P. (1996) Suomalaisten matematiikan ja luonnontieteiden osaaminen vuonna 2002: kansalliset kehittämistalkoot [Finnish knowhow in mathematics and natural sciences in 2002 : joint national action]. Koulutus- ja tiedepolitiikan linjan julkaisusarja ; 38. Helsinki : Opetusministeriö.

Krzywacki, H. (2009). Becoming a teacher: emerging teacher identity in mathematics teacher education. Research Report 308. Department of Applied Sciences of Education. University of Helsinki. (available in http://urn.fi/URN:ISBN:978-952-10-5757-1)

Kupari, P. (1999). Laskutaitoharjoittelusta ongelmanratkaisuun. Matematiikan opettajien matematiikkauskomukset opetuksen muovaajina. [From practising computational skills to problem solving. Mathematics teachers' mathematical beliefs and the construction of their teaching.] Jyväskylän yliopisto: Koulutuksen tutkimuslaitos, tutkimuksia 7.

Laine, A. \& Kaasila, R. (2007). Mathematics education in primary teacher program. In E. Pehkonen, M. Ahtee \& J. Lavonen (Eds.) How Finns learn mathematics and science (pp. 133141). Rotterdam: Sense Publishers.

Lilli, M., Ranta, P., Hänninen, L. \& Laine, A. (2010). Matikkamatka 5 syksy. Opettajan opas. Helsinki: Osakeyhtiö Tammi.

Merenluoto, K. \& Lehtinen, E. (2004). Number concept and conceptual change. Towards systemic model of the processes of change. Learning and Instruction 14 (5), 519-534.

Ministry of Education 2012. Education and research 2011 - 2016. A Development Plan. Available in http://www.minedu.fi/export/sites/default/OPM/Julkaisut/2012/liitteet/okm03.pdf?lang=fi 
The new distribution of lesson hours in basic education (pdf, in Finnish)

Available in: http;//www.oph.fi/english/curricula_and_qualifications/basic_education

Niemi, E (2004). Perusopetuksen oppimistulosten kansallinen arviointi ja tulosten hyödyntäminen koulutuspoliittisessa kontekstissa. Perusopetuksen matematiikan oppimistulosten kansallinen arviointi 6. vuosiluokalla vuonna 2000. [The National Evaluation and Exploitation in Education Policy of Learning Results in Primary Education. The National Evaluation of the Education Outcomes in Mathematics in the Sixth Grade of primary Education in the Year 2000] Turku: Turun yliopiston julkaisuja C 216.

Niemi, E (2008). Matematiikan oppimistulosten kansallinen arviointi 6. vuosiluokalla vuonna 2007. Oppimistulosten arviointi 1/2008. Opetushallitus.

Norris, N., Aspland, R., MacDonald, B., Schostak, J. \& Zamorski, B. (1996). An independent evaluation of comprehensive curriculum reform in Finland, Helsinki: National Board of Education.

OECD (2004) Problem solving for tomorrow's world: first measures of cross-curricular competencies from PISA 2003. Organisation for Economic Co-operation and Development. Paris : OECD. Available in http://www.oecd.org/document/54/0,2340,en_32252351_32236173_34002550_1_1_1_1,00.ht $\underline{\mathrm{ml}}$

OECD (2010). PISA 2009 Results: What students know and can do-student performance in reading, mathematics and science. Volume I. Retrieved from http://dx.doi.org/10.1787/9789264091450-en

Pehkonen, L. (2004a). How Finnish education meets the needs of the gifted? In J. Touron (Ed.), Proceedings of the $9^{\text {th }}$ Conference of the European Council for High Ability 2004. University of Navarra.

Pehkonen, L. (2004b).The magic circle of the textbook - an option or obstacle for teachers change. In M. J. Høines \& A. B. Fuglestad (Eds.), Proceedings of the $28^{\text {th }}$ Conference of the 
International Group for the Psychology of Mathematics Education, Vol 3, pp. 513 - 520. Bergen University College.

Pehkonen, L. (2007). To change or not to change - How primary school teachers speak about stability and change. Nordic Studies in Mathematics Education 12 (2), 57-76.

Pietilä, A. (2002). the role of mathematics experiences in forming pre-service elementary teachers' views of mathematics. In A. Cockburn \& E. Nardi (Eds.). Proceedings of the PME 26, Vol. 4, pp. 57-64. Norwich: University of East Anglia.

Opetushallitus (1995). Toimi, laske ja ajattele [Act, Count and Reflect]. Helsinki:

Opetushallitus [National Board of Education].

Simola, H. (2002). Finnish Teachers Talking about Their Changing Work. In K. Klette, I Carlgren, J. Rasmussen, \& H: Simola (Eds.) Restructuring Nordic Teachers: Analysis of interviews with Danish, Finnish, Swedish and Norwegian Teachers, pp. 49 -70. Oslo: University of Oslo, Institute for Educational Research. Report 3.

Simola, H. \& Hakala, K. (2001). School Professionals Talk about Educational Change Interviews with Finnish school level actors on educational governance and social inclusion/exclusion. In S. Lindblad \& T. Popkewitz (Eds.) Listening to Education Actors on Governance and Social Integration and Exclusion, pp. 103 -132. Uppsala: University of Uppsala, Department of Education, Uppsala reports on Education 37.

Välijärvi, J., Linnakylä, P., Kupari, P., Reinikainen, P. \& Arffman, I. (2002). The Finnish Success in Pisa - and some reasons behind it: PISA 2000. Jyväskylä: University of Jyväskylä, Institute for Educational Research. 